\title{
DEATHS OF CHILDREN IN GREATER LONDON 1966
}

\author{
ROMA CHAMBERLAIN, M.B., Ch.B., D.C.H., D.R.C.O.G. \\ Lecturer in Paediatrics, St. Mary's Hospital Medical School
}

AND

\author{
G. B. HILL, M.B., Ch.B., M.Sc. \\ Senior Medical Statistician, General Register Office
}

The high death rate among infants at or immediately after birth compared with that for older children has focused attention on the prevention of perinatal and infant mortality and comparatively little notice has been taken of what has been happening to the mortality rates among older children in the last 10 years or so.

The 1940s were characterized by a rapid decline in mortality rates of all children in England and Wales. The speed of decline of infant mortality rates slowed during the late 1940 s and early 1950 s but, except for a short pause at the beginning of the 1960 s, has continued to decrease steadily until the present time (Fig. 1). The older children show a different pattern. The rapid drop in the 1940s, generally attributed to antibiotics and immunization, continued with a decreased momentum until the

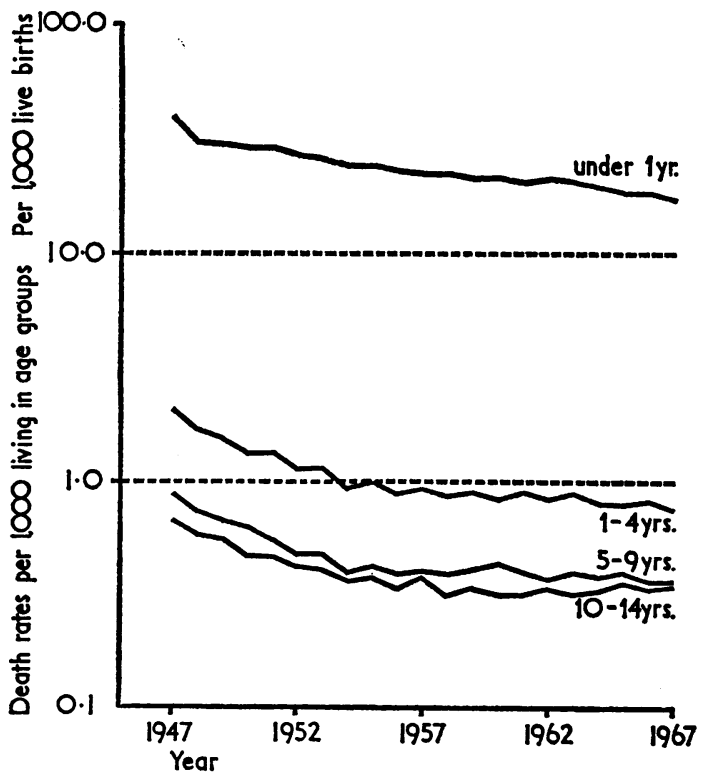

Fic. 1.-Death rates for children under 15 years of age, 1947-67, England and Wales. middle of the 1950s but, with a few minor fluctuations, has remained practically stationary since then.

While the sociological and environmental factors which affect perinatal and neonatal mortality have been well documented over many years, deaths among older children have rarely been analysed in this way. Studies on older children have usually been undertaken on individual diseases only, e.g., leukaemia, often confined to hospital centres and over long periods to amass sufficient cases. A few have used matched controls and some have been related to defined areas of population.

To see whether the analysis used in the study of $\vec{\theta}$ perinatal mortality could be applied to child deaths? it was decided to look at the death registration form Originally the intention was to find out the propor-? tion of children who died outside hospital but the form contained a number of other relevant facts which are not normally analysed for children, and it was decided to include these also.

\section{Methods}

Greater London has a population of $1,542,280$ children under the age of 15 years according to the 1966 Census. The area is well defined and large enough to provide meaningful figures for one year, there being about 3,000 deaths a year. A number of children from abroad are admitted to London hospitals for highly specialized care, and the deaths of these children were excluded. The enquiry was confined to children under the age of 15 who died during 1966.

The age of the child is usually well recorded and for younger children the date of birth is often given as well. It was found possible to record the age in minutes for those who died under one hour of age, hours for those who survived one day, days for those surviving one week and so on.

The day and the month of the death were available for all except a few infanticide and homicide cases.

The place of residence was analysed according to the London Borough in which the child or parent 
resided; these were then regrouped into inner and outer boroughs. This was done to see whether the known tendency for infant mortality rates to be higher in the centre of towns also applied to London and was equally true of the older age groups.

The place of death was called hospital when the address was known to be a National Health Service or private hospital or nursing home. Children stated to be dead on arrival or to have died on the way to hospital were coded as 'died on the way to hospital', although it is probable that some were dead before they started the journey. The remainder were coded to 'elsewhere', the majority having died at home.

Normally the General Register Office does not analyse the socio-economic groups of children under the age of 15 years. The occupation of the father, or of the mother in the case of illegitimate children, is recorded on the death registration form. It was decided to code the deaths of legitimate children to the five social classes, keeping separate those with fathers described as students or members of the armed forces. Deaths of illegitimate children were coded as a group whether or not there was evidence of cohabitation. This was done by the staff of the General Register Office.

The cause of death was first coded using the four-digit code of the International Statistical Classification of Diseases, Injuries, and Causes of Death (7th Revision). For deaths with multiple causes two were coded, primary and secondary. The primary cause was not always the same as the official underlying cause of death, although in the majority of cases this was so. If it was considered medically more sensible not to follow exactly the order of cause of death as given by the doctor signing the certificate, this was done.

The grouping of diseases under chapter headings in the International Classification is not always meaningful when applied to children; for example, not all congenital abnormalities are included in the chapter of this name. It was decided, therefore, to regroup them. Many neonatal deaths may have two or three causes, e.g., a maternal cause such as toxaemia, and perhaps two causes related to the child, such as respiratory distress syndrome and prematurity, while in others prematurity may be the only cause given. Deaths due to maternal causes were, therefore, coded separately and all deaths were allocated to a cause related to the child. To ensure that all cases of prematurity had been recorded, if it was mentioned on the death certificate it was given a special code independently of whether prematurity was the primary cause of death or not. The causes in the Diseases of Infancy chapter were redistributed; those which were a direct result of the birth were called 'perinatal' causes and the remainder were allocated to the appropriate section regardless of age, e.g., pneumonia of the newborn was included among the respiratory diseases, whereas respiratory distress syndrome and respiratory failure in the newborn appear under 'perinatal' causes. All congenital abnormalities were grouped together, including conditions such as Down's syndrome and abdominal hernias. Table I shows the system used. If a death

TABLE I

RE-GROUPING OF ICD (7TH REVISION) USED FOR ANALYSING THE CAUSES OF DEATH, WITH NUMBERS OF DEATHS

\begin{tabular}{|c|c|c|}
\hline \multicolumn{3}{|c|}{ Deaths $0-14$ years for 1966 in Greater London } \\
\hline Disease Group with ICD Numbers & No. & Per cent. \\
\hline 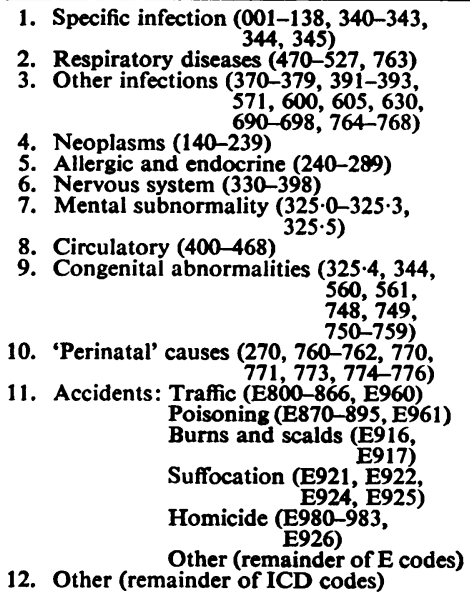 & $\begin{array}{r}632 \\
1,273 \\
96 \\
6 \\
55 \\
38 \\
18 \\
70 \\
101\end{array}$ & $\begin{array}{r}19.6 \\
39.5 \\
3 \cdot 0 \\
0.2 \\
1 \cdot 7 \\
1 \cdot 2 \\
0.6 \\
2.2 \\
3 \cdot 1\end{array}$ \\
\hline Total & 3,222 & $100 \cdot 1$ \\
\hline
\end{tabular}

had a Coroner's post-mortem (although not necessarily an inquest) and the death certificate had been signed by the coroner, this was coded.

\section{Results}

After excluding the deaths of children with a foreign address, there were 3,222 forms. Thirteen were incomplete for some items, leaving 3,209 for analysis.

\section{Age ANd Sex}

Forty-one per cent of the children were girls. Table II shows the age range; $55 \%$ died before they were 1 month old, $23 \%$ during the remainder of the first year, and $22 \%$ were over the age of 1 year at death. 
TIME OF YeAR

The seasonal distribution of the deaths varied with age at death (Table III). Neonatal deaths reflected the underlying seasonality of births with a peak in March. Deaths in the post-neonatal and pre-school periods had a winter peak, whilst at older ages the summer increase in the accident rates showed through in the figures.

\section{Place of Residence}

Just over half the deaths occurred in the outer London boroughs but, if these are related to the population, then the rates for each group are higher in the centre of the conurbation. London, therefore, despite its large size and lack of uniformity, tends to act in the same way as other large towns but Table IV shows that the rate of decline by age is greater in the inner boroughs so that by the age of 10-14 years there is little difference.

\section{Place of Death}

The place of death has important implications for the provision of the services and therefore the prevention of death.

Ninety-five per cent of the babies under 1 month died in hospital. Table V shows that this proportion declined among the older babies, so that between 1 month and 1 year only $65 \%$ died in hospital, $7 \%$ died on the way to hospital, and the remainder died elsewhere, usually in their own homes. After this age about three-quarters of the children died in hospital, the smallest proportion being among the postneonatal age group. The percentage who died on the way to hospital was slightly greater in October to

TABLE II

NUMBER OF DEATHS ACCORDING TO AGE WITH PERCENTAGE DISTRIBUTION

\begin{tabular}{|c|c|c|c|c|c|c|c|c|c|}
\hline & \multicolumn{4}{|c|}{ Neonatal } & \multirow{2}{*}{$\begin{array}{c}\text { Post- } \\
\text { neonatal }\end{array}$} & \multirow{2}{*}{$\begin{array}{c}1-4 \\
\text { years }\end{array}$} & \multirow{2}{*}{$\begin{array}{c}5-9 \\
\text { years }\end{array}$} & \multirow{2}{*}{$\begin{array}{l}10-14 \\
\text { years }\end{array}$} & \multirow[b]{2}{*}{ Total } \\
\hline & $\begin{array}{l}\text { Under } \\
1 \text { hour }\end{array}$ & $\begin{array}{c}1-23 \\
\text { hours }\end{array}$ & $\begin{array}{c}1-7 \\
\text { days }\end{array}$ & $\begin{array}{c}1-4 \\
\text { weeks }\end{array}$ & & & & & \\
\hline No. & 178 & 756 & 625 & 189 & 734 & 385 & 198 & 144 & 3,209 \\
\hline \multirow{2}{*}{ Percentage distribution } & 6 & 24 & 19 & 6 & \multirow{2}{*}{23} & \multirow{2}{*}{12} & \multirow{2}{*}{6} & \multirow{2}{*}{4} & \multirow{2}{*}{100} \\
\hline & \multicolumn{4}{|c|}{55} & & & & & \\
\hline
\end{tabular}

TABLE III

MONTH OF DEATH WITH PERCENTAGE DISTRIBUTION

\begin{tabular}{|c|c|c|c|c|c|c|c|c|c|c|c|c|c|c|}
\hline & & Jan. & Feb. & Mar. & Apr. & May & Jun. & Jul. & Aug. & Sep. & Oct. & Nov. & Dec. & Total \\
\hline Neonatal & $\begin{array}{l}\text { No. } \\
\%\end{array}$ & $\begin{array}{l}142 \\
8 \cdot 1\end{array}$ & $\begin{array}{c}151 \\
8.6\end{array}$ & $\begin{array}{r}177 \\
10.1\end{array}$ & $\begin{array}{r}148 \\
8.5\end{array}$ & $\begin{array}{r}125 \\
7 \cdot 2\end{array}$ & $\begin{array}{r}151 \\
8.6\end{array}$ & $\begin{array}{r}149 \\
8.5\end{array}$ & $\begin{array}{r}123 \\
7 \cdot 0\end{array}$ & $\begin{array}{c}142 \\
8 \cdot 1\end{array}$ & $\begin{array}{r}144 \\
8.2\end{array}$ & $\begin{array}{r}144 \\
8 \cdot 2\end{array}$ & $\begin{array}{r}152 \\
8 \cdot 7\end{array}$ & $\begin{array}{r}1,748 \\
100\end{array}$ \\
\hline Post-neonatal & $\begin{array}{l}\text { No. } \\
\%\end{array}$ & $\begin{array}{r}82 \\
11 \cdot 2\end{array}$ & $\begin{array}{r}85 \\
11 \cdot 6\end{array}$ & $\begin{array}{r}64 \\
8 \cdot 7\end{array}$ & $\begin{array}{r}55 \\
7 \cdot 5\end{array}$ & $\begin{array}{r}43 \\
5.9\end{array}$ & $\begin{array}{r}44 \\
6.0\end{array}$ & $\begin{array}{r}44 \\
6.0\end{array}$ & $\begin{array}{r}56 \\
7 \cdot 6\end{array}$ & $\begin{array}{r}51 \\
6.9\end{array}$ & $\begin{array}{r}54 \\
7 \cdot 4\end{array}$ & $\begin{array}{r}67 \\
9 \cdot 1\end{array}$ & $\begin{array}{r}89 \\
12 \cdot 1\end{array}$ & $\begin{array}{l}734 \\
100\end{array}$ \\
\hline $1-4$ years & $\begin{array}{l}\text { No. } \\
\%\end{array}$ & $\begin{array}{r}48 \\
12 \cdot 5\end{array}$ & $\begin{array}{r}37 \\
9.6\end{array}$ & $\begin{array}{r}34 \\
8 \cdot 8\end{array}$ & $\begin{array}{r}33 \\
8 \cdot 6\end{array}$ & $\begin{array}{r}24 \\
6 \cdot 2\end{array}$ & $\begin{array}{r}18 \\
4 \cdot 7\end{array}$ & $\begin{array}{r}30 \\
7 \cdot 8\end{array}$ & $\begin{array}{r}31 \\
8 \cdot 1\end{array}$ & $\begin{array}{r}26 \\
6.8\end{array}$ & $\begin{array}{r}29 \\
7 \cdot 5\end{array}$ & $\begin{array}{r}35 \\
9 \cdot 1\end{array}$ & $\begin{array}{r}40 \\
10 \cdot 4\end{array}$ & $\begin{array}{l}385 \\
100\end{array}$ \\
\hline $5-14$ years & $\begin{array}{l}\text { No. } \\
\%\end{array}$ & $\begin{array}{r}30 \\
8 \cdot 8\end{array}$ & $\begin{array}{r}18 \\
5 \cdot 3\end{array}$ & $\begin{array}{r}37 \\
10 \cdot 8\end{array}$ & $\begin{array}{r}31 \\
9 \cdot 1\end{array}$ & $\begin{array}{r}30 \\
8 \cdot 8\end{array}$ & $\begin{array}{r}23 \\
6 \cdot 7\end{array}$ & $\begin{array}{r}33 \\
9.6\end{array}$ & $\begin{array}{r}33 \\
9 \cdot 6\end{array}$ & $\begin{array}{r}23 \\
6 \cdot 7\end{array}$ & $\begin{array}{r}31 \\
9 \cdot 1\end{array}$ & $\begin{array}{r}28 \\
8 \cdot 2\end{array}$ & $\begin{array}{r}25 \\
7 \cdot 3\end{array}$ & $\begin{array}{l}342 \\
100\end{array}$ \\
\hline All ages & $\begin{array}{l}\text { No. } \\
\%\end{array}$ & $\begin{array}{r}302 \\
9.4\end{array}$ & $\begin{array}{c}291 \\
9 \cdot 1\end{array}$ & $\begin{array}{l}312 \\
9.7\end{array}$ & $\begin{array}{r}267 \\
8 \cdot 3\end{array}$ & $\begin{array}{r}222 \\
6.9\end{array}$ & $\begin{array}{r}236 \\
7 \cdot 4\end{array}$ & $\begin{array}{r}256 \\
8.0\end{array}$ & $\begin{array}{r}243 \\
7.6\end{array}$ & $\begin{array}{r}242 \\
7.5\end{array}$ & $\begin{array}{l}258 \\
8.0\end{array}$ & $\begin{array}{l}274 \\
8.5\end{array}$ & $\begin{array}{c}306 \\
9.5\end{array}$ & $\begin{array}{r}3,209 \\
100\end{array}$ \\
\hline
\end{tabular}

TABLE IV

DEATHS ACCORDING TO PLACE OF RESIDENCE

\begin{tabular}{|c|c|c|c|c|c|c|c|c|c|c|c|c|}
\hline & \multicolumn{2}{|c|}{ Neonatal } & \multicolumn{2}{|c|}{ Post-neonatal } & \multicolumn{2}{|c|}{$1-4$ years } & \multicolumn{2}{|c|}{ 5-9 years } & \multicolumn{2}{|c|}{$10-14$ years } & \multicolumn{2}{|c|}{ Total } \\
\hline & No. & Rate* & No. & Rate* & No. & Rate† & No. & Rate† & No. & Rate† & No. & Ratef \\
\hline $\begin{array}{l}\text { Inner London boroughs } \\
\text { Outer London boroughs }\end{array}$ & $\begin{array}{l}844 \\
904\end{array}$ & $\begin{array}{l}142 \cdot 5 \\
110 \cdot 7\end{array}$ & $\begin{array}{l}373 \\
361\end{array}$ & $\begin{array}{l}63 \cdot 0 \\
44 \cdot 2\end{array}$ & $\begin{array}{l}185 \\
200\end{array}$ & $\begin{array}{l}9 \cdot 9 \\
7 \cdot 2\end{array}$ & $\begin{array}{r}78 \\
120\end{array}$ & $\begin{array}{l}4 \cdot 2 \\
3 \cdot 8\end{array}$ & $\begin{array}{l}57 \\
87\end{array}$ & $\begin{array}{l}3 \cdot 4 \\
3 \cdot 1\end{array}$ & $\begin{array}{l}1,537 \\
1,672\end{array}$ & $\begin{array}{l}26 \cdot 0 \\
17 \cdot 6\end{array}$ \\
\hline Total & 1,748 & $124 \cdot 1$ & 734 & $52 \cdot 1$ & 385 & $8 \cdot 3$ & 198 & $4 \cdot 0$ & 144 & $3 \cdot 2$ & 3,209 & $20 \cdot 8$ \\
\hline
\end{tabular}

- Per 10,000 livebirths.

+ Per 10,000 children in each age group. 
TABLE V

PLACE OF DEATH IN AGE GROUPS WITH PERCENTAGE DISTRIBUTION

\begin{tabular}{|c|c|c|c|c|c|c|c|c|c|c|c|c|}
\hline & \multicolumn{2}{|c|}{ Neonatal } & \multicolumn{2}{|c|}{ Post-neonatal } & \multicolumn{2}{|c|}{$1-4$ years } & \multicolumn{2}{|c|}{ 5-9 years } & \multicolumn{2}{|c|}{ 10-14 years } & \multicolumn{2}{|c|}{ Total } \\
\hline & No. & $\%$ & No. & $\%$ & No. & $\%$ & No. & $\%$ & No. & $\%$ & No. & $\%$ \\
\hline Total & 1,748 & 99 & 734 & 99 & 385 & 99 & 198 & 101 & 144 & 100 & 3,209 & 100 \\
\hline 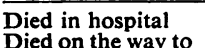 & 1,668 & 95 & 479 & 65 & 290 & 75 & 150 & 76 & 111 & 77 & 2,698 & 84 \\
\hline $\begin{array}{l}\text { hospital } \\
\text { Died elsewhere }\end{array}$ & $\begin{array}{r}3 \\
77\end{array}$ & $\begin{array}{l}0 \\
4\end{array}$ & $\begin{array}{r}54 \\
201\end{array}$ & $\begin{array}{r}7 \\
27\end{array}$ & $\begin{array}{l}25 \\
70\end{array}$ & $\begin{array}{r}6 \\
18\end{array}$ & $\begin{array}{r}9 \\
39\end{array}$ & $\begin{array}{r}5 \\
20\end{array}$ & $\begin{array}{r}6 \\
27\end{array}$ & $\begin{array}{r}4 \\
19\end{array}$ & $\begin{array}{r}97 \\
414\end{array}$ & $\begin{array}{r}3 \\
13\end{array}$ \\
\hline
\end{tabular}

December than in the summer months, but was unaffected by the place of residence or social class of the child.

As can be seen in Fig. 2, the place of death varies considerably with the cause of death; accidents and respiratory deaths both showing a higher than average proportion of deaths occurring outside hospital.

\section{Social Class}

Fifteen per cent of the deaths were in social classes I and II, $43 \%$ were in social class III, and $25 \%$ were in social classes IV and V. In $12 \%$ the

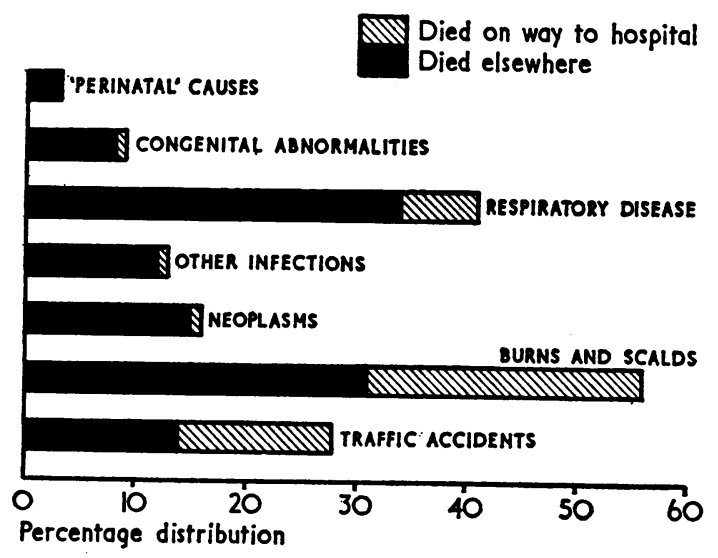

FIG. 2.-Proportion of children dying outside hospital, according to diagnosis, 1966, Greater London. births were illegitimate, in $1 \%$ the father was in the armed forces, in $2 \%$ he was a student, and for $1 \%$ the social class could not be determined. To examine the rates among the different age groups it was necessary to make adjustments to compensate for the fact that as illegitimate children get older they tend to become legitimized. Some data relevant to this question were obtained by a generation study of illegitimate children (Registrar General's Statistical Review of England and Wales for the year 1966, Part III, Commentary, p. 74). Using these figures and the social class breakdown from the 1961 Census, it was possible to estimate the populations at risk. It appears, however, that the degree of legitimization at later ages of childhood is underestimated by these calculations. In Table VI and subsequent tables the legitimate children of students and men with unknown occupations were included with social class III and the children of those in the armed forces among social classes IV and V.

The adverse effects of social classes IV and $V$ on mortality in the early months of life is well known. Social classes I and II are normally combined together in studies of this nature because the numbers are usually small. The last official published figures which distinguished the two classes were for 1949-53 (Registrar General's Decennial Supplement for 1951) and showed a steady gradient for infane mortality from 50.9 per 1,000 births in social class $\mathrm{V}$ to 18.7 per 1,000 births in social class $\mathrm{I}$. The 1958 Perinatal Mortality Survey (Butler and Bonham,

TABLE VI

DEATH RATES PER 10,000 CHILDREN IN EACH AGE GROUP ACCORDING TO SOCIAL CLASS

\begin{tabular}{|c|c|c|c|c|c|c|c|c|c|c|c|c|}
\hline \multirow{2}{*}{ Social Class } & \multicolumn{2}{|c|}{ Neonatal } & \multicolumn{2}{|c|}{ Post-neonatal } & \multicolumn{2}{|c|}{$1-4$ years } & \multicolumn{2}{|c|}{$5-9$ years } & \multicolumn{2}{|c|}{$10-14$ years } & \multicolumn{2}{|c|}{ Total } \\
\hline & No. & Rate $^{\circ}$ & No. & Rate $^{\circ}$ & No. & Rate & No. & Rate & No. & Rate & No. & Rate \\
\hline $\begin{array}{l}\text { I and II } \\
\text { III* } \\
\text { IV and V† } \\
\text { Illegitimate }\end{array}$ & $\begin{array}{l}240 \\
795 \\
435 \\
278\end{array}$ & $\begin{array}{r}92.5 \\
120.3 \\
129.8 \\
180.7\end{array}$ & $\begin{array}{r}94 \\
352 \\
210 \\
78\end{array}$ & $\begin{array}{l}36 \cdot 1 \\
53 \cdot 1 \\
62 \cdot 4 \\
52 \cdot 3\end{array}$ & $\begin{array}{r}55 \\
174 \\
119 \\
37\end{array}$ & $\begin{array}{r}6.5 \\
8.0 \\
10.8 \\
6.9\end{array}$ & $\begin{array}{r}43 \\
101 \\
50 \\
4\end{array}$ & $\begin{array}{l}4 \cdot 6 \\
4 \cdot 2 \\
4 \cdot 1 \\
0 \cdot 9\end{array}$ & $\begin{array}{r}35 \\
68 \\
38 \\
3\end{array}$ & $\begin{array}{l}4 \cdot 4 \\
3 \cdot 0 \\
3 \cdot 4 \\
1 \cdot 1\end{array}$ & $\begin{array}{r}467 \\
1,490 \\
852 \\
400\end{array}$ & $\begin{array}{l}16 \cdot 2 \\
20 \cdot 3 \\
22 \cdot 9 \\
27 \cdot 2\end{array}$ \\
\hline Total & 1,748 & $124 \cdot 1$ & 734 & $52 \cdot 1$ & 385 & $8 \cdot 3$ & 198 & $4 \cdot 0$ & 144 & $3 \cdot 2$ & 3,209 & 20.8 \\
\hline
\end{tabular}

- Includes students and not known.

$t$ Includes armed forces.

Includes armed forces.
Per 10,000 live births. 
1963) also showed a similar slope for the country as a whole but not for London and the south-east of England. Here the mortality ratio for the region was 90 (compared with $\mathbf{1 0 0}$ for the whole survey), and the ratio for social class I was 79 compared with 64 for social class II. Grundy and Lewis Faning (1957), in a study on morbidity and mortality in the first year of life in 15 selected areas, found that the mortality rates were slightly higher in social class I than in social class II. We found that the rates in social class I were consistently higher than in social class II. On their own these figures are small; taking into account the findings already mentioned, they seem worth examining further. It may be that London, with a high proportion of upper social classes and containing the well-known teaching hospitals, may attract social class I families when the child becomes ill, but it is unlikely that these families would give a London address as their normal place of residence.

The effect of social classes IV and V on mortality in the early months of life apparently declines in importance as the child gets older, so that by the age of 10-14 years, in Greater London at least, social classes I and II have the highest rates, as shown in Table VI. Except occasionally for infant mortality, national mortality statistics are not analysed by social class for children under the age of 15 , so that it is not known whether this is an isolated phenomenon associated with London. It would be of interest to see the national figures.

\section{Individual Causes of Death}

Table VII shows the major causes of death in the various age groups, where the age of the child was known. These are not comparable to the official statistics because, as explained above, they have been grouped as in Table I.

'Perinatal' Causes. There were 1,272 deaths due to causes associated with birth. Not all children died immediately after birth, a small percentage surviving longer than one month. The sex ratio was the same as for all deaths. These causes accounted for $72 \%$ of the neonatal deaths and for $1.4 \%$ of the post-neonatal deaths. The rates were higher among the lower social groups and among those living in the centre of the conurbation. Prematurity was recorded as the primary or contributory cause of death in $72 \%$.

Congenttal Abnormalities. There were 632 deaths from congenital abnormalities, giving a $\vec{O}$

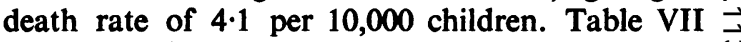
shows that they were a major cause of death in each $\omega$ age group, the rate being highest among the young $\overrightarrow{\widehat{D}}$ children and declining in the older ages but still $\stackrel{\circ}{\vec{y}}$ remaining the third highest cause among the 10-14 i year olds. The number of girls was slightly lower (45\%) than that of the boys (55\%). Month of death $\vec{\omega}$ closely followed the pattern of the deaths as a whole.

Place of Residence and Death. The death rates were slightly higher in the inner boroughs, 4.8 per 10,000 compared with 3.7 in the outer boroughs. Ninety-one per cent of the deaths occurred in hospital, $0.6 \%$ on the way to hospital and the remainde $\overrightarrow{0}$ elsewhere. Twenty-three per cent of the deaths were certified by the coroner.

Social Class. Table VIII shows the rates per 10,000 children according to social class. Among the younger children the rates were highest in social classes IV and V and among the illegitimate. This social class gradient is reversed at ages 5 and over but the numbers are too small to be conclusive.

Neoplasms. There were 133 deaths from neoplasms, $47 \%$ girls and $53 \%$ boys. Table VII shows the age distribution and the rates per 10,000 children. The rate was lowest in the neonatal period, rising to

TABLE VII

CAUSES OF DEATH ACCORDING TO AGE AND THE RATES PER 10,000 IN EACH AGE GROUP

\begin{tabular}{|c|c|c|c|c|c|c|c|c|c|c|c|c|}
\hline & \multicolumn{2}{|c|}{ Neonatal } & \multicolumn{2}{|c|}{ Post-neonatal } & \multicolumn{2}{|c|}{$1-4$ years } & \multicolumn{2}{|c|}{ 5-9 years } & \multicolumn{2}{|c|}{$10-14$ years } & \multicolumn{2}{|c|}{ Total } \\
\hline & No. & Rate* & No. & Rate* & No. & Rate & No. & Rate & No. & Rate & No. & Rate \\
\hline $\begin{array}{l}\text { Respiratory diseases } \\
\text { Other infections } \\
\text { Neoplasms } \\
\text { Congenital abnormalities } \\
\text { 'Perinatal' causes } \\
\text { Traffic accidents } \\
\text { Burns and scalds } \\
\text { Sufiocation } \\
\text { Remainder }\end{array}$ & $\begin{array}{r}73 \\
26 \\
3 \\
353 \\
1,260 \\
0 \\
1 \\
7 \\
25\end{array}$ & $\begin{array}{r}5 \cdot 2 \\
18 \cdot 5 \\
0 \cdot 2 \\
25 \cdot 1 \\
89 \cdot 4 \\
0 \\
0 \cdot 1 \\
0 \cdot 5 \\
1 \cdot 8\end{array}$ & $\begin{array}{r}355 \\
70 \\
12 \\
177 \\
10 \\
3 \\
6 \\
24 \\
77\end{array}$ & $\begin{array}{r}25 \cdot 2 \\
5 \cdot 0 \\
0 \cdot 9 \\
12 \cdot 6 \\
0 \cdot 7 \\
0 \cdot 2 \\
0 \cdot 4 \\
1 \cdot 7 \\
5 \cdot 5\end{array}$ & $\begin{array}{r}76 \\
39 \\
54 \\
57 \\
1 \\
30 \\
35 \\
6 \\
87\end{array}$ & $\begin{array}{l}1 \cdot 6 \\
0 \cdot 8 \\
1 \cdot 2 \\
1 \cdot 2 \\
0 \cdot 0 \\
0 \cdot 6 \\
0 \cdot 8 \\
0 \cdot 1 \\
1 \cdot 9\end{array}$ & $\begin{array}{r}16 \\
10 \\
37 \\
32 \\
1 \\
36 \\
9 \\
0 \\
57\end{array}$ & $\begin{array}{r}0 \cdot 3 \\
0 \cdot 2 \\
0 \cdot 7 \\
0 \cdot 6 \\
0 \cdot 0 \\
0 \cdot 7 \\
0 \cdot 2 \\
0 \\
1 \cdot 1\end{array}$ & $\begin{array}{r}8 \\
8 \\
27 \\
13 \\
0 \\
27 \\
3 \\
1 \\
57\end{array}$ & $\begin{array}{r}0 \cdot 2 \\
0 \cdot 2 \\
0 \cdot 6 \\
0 \cdot 3 \\
0 \\
0 \cdot 6 \\
0 \cdot 1 \\
0 \cdot 0 \\
1 \cdot 3\end{array}$ & $\begin{array}{r}528 \\
153 \\
133 \\
632 \\
1,272 \\
96 \\
54 \\
38 \\
303\end{array}$ & $\begin{array}{l}3 \cdot 4 \\
1 \cdot 0 \\
0.9 \\
4 \cdot 1 \\
8 \cdot 3 \\
0.6 \\
0 \cdot 4 \\
0 \cdot 3 \\
2 \cdot 0\end{array}$ \\
\hline Total & 1,748 & $124 \cdot 1$ & 734 & $52 \cdot 1$ & 385 & $8 \cdot 3$ & 198 & $4 \cdot 0$ & 144 & $3 \cdot 2$ & 3,209 & $20 \cdot 8$ \\
\hline
\end{tabular}

- Per 10,000 live births. 
TABLE VIII

DEATH RATES FOR CONGENITAL ABNORMALITIES PER 10,000 CHILDREN IN EACH AGE GROUP ACCORDING TO SOCIAL CLASS

\begin{tabular}{|c|c|c|c|c|c|c|c|c|c|c|c|c|}
\hline \multirow{2}{*}{ Social Class } & \multicolumn{2}{|c|}{ Neonatal } & \multicolumn{2}{|c|}{ Post-neonatal } & \multicolumn{2}{|c|}{$1-4$ years } & \multicolumn{2}{|c|}{$5-9$ years } & \multicolumn{2}{|c|}{ 10-14 years } & \multicolumn{2}{|c|}{ Total } \\
\hline & No. & Rate $^{\circ}$ & No. & Rate $^{\circ}$ & No. & Rate & No. & Rate & No. & Rate & No. & Rate \\
\hline $\begin{array}{l}\text { I and II } \\
\text { III } \\
\text { IV and Vt } \\
\text { Illegitimate }\end{array}$ & $\begin{array}{r}55 \\
161 \\
95 \\
42\end{array}$ & $\begin{array}{l}21 \cdot 2 \\
24 \cdot 4 \\
28 \cdot 4 \\
27 \cdot 3\end{array}$ & $\begin{array}{l}20 \\
95 \\
48 \\
14\end{array}$ & $\begin{array}{r}7.7 \\
14.3 \\
14.3 \\
9.4\end{array}$ & $\begin{array}{r}9 \\
29 \\
15 \\
4\end{array}$ & $\begin{array}{l}1.1 \\
1.3 \\
1.4 \\
0.7\end{array}$ & $\begin{array}{r}8 \\
14 \\
8 \\
2\end{array}$ & $\begin{array}{l}0.9 \\
0.6 \\
0.7 \\
0.4\end{array}$ & $\begin{array}{l}4 \\
5 \\
4 \\
0\end{array}$ & $\begin{array}{l}0.5 \\
0.2 \\
0.4 \\
0\end{array}$ & $\begin{array}{r}96 \\
304 \\
170 \\
62\end{array}$ & $\begin{array}{l}3 \cdot 3 \\
4 \cdot 1 \\
4 \cdot 6 \\
4 \cdot 2\end{array}$ \\
\hline Total & 353 & $25 \cdot 1$ & 177 & $12 \cdot 6$ & 57 & $1 \cdot 2$ & 32 & 0.6 & 13 & 0.3 & 632 & $4 \cdot 1$ \\
\hline
\end{tabular}

- Includes students and unknown.

$\dagger$ Includes armed forces.

Per 10,000 live births.

the 1-4 year old group where it reached the peak and then declined.

Month of Year. There was a slightly higher proportion of deaths in the winter than in the summer but this is more likely to reflect the incidence of secondary causes rather than any epidemiological pattern of the abnormalities.

Place of Residence and Death. There was no statistically significant difference between the death rates in the inner and outer boroughs. Eighty-four per cent died in hospital. Ten per cent had a coroner's inquest.
Social Class. Table IX shows the social class pattern among deaths from neoplasm. The rates for the social class groups differ significantly $(P<0.05)$, the rate for classes I and II being highest at all ages.

Table X shows that this pattern was consistent for all sites except neoplasm of the central nervous system. The result is surprising for this country. In a survey of childhood malignancies, Stewart, Webb, and Hewitt (1958) found 'no social class or economic distinctions as between cases and controls or between cases of leukaemia and cases of other cancer'. Campbell, Gaisford, Paterson, and Steward (1961), reviewing tumours in children in Manchester, found no social class differences. Knox (1964), reviewing

TABLE IX

DEATHS FROM NEOPLASMS: NUMBERS AND RATES PER 10,000 CHILDREN IN EACH AGE GROUP ACCORDING TO SOCIAL CLASS

\begin{tabular}{|c|c|c|c|c|c|c|c|c|c|c|c|c|}
\hline \multirow{2}{*}{ Social Class } & \multicolumn{2}{|c|}{ Neonatal } & \multicolumn{2}{|c|}{ Post-neonatal } & \multicolumn{2}{|c|}{$1-4$ years } & \multicolumn{2}{|c|}{ 5-9 years } & \multicolumn{2}{|c|}{ 10-14 years } & \multicolumn{2}{|c|}{ Total } \\
\hline & No. & Rate $^{\circ}$ & No. & Rate $^{\circ}$ & No. & Rate & No. & Rate & No. & Rate & No. & Rate \\
\hline $\begin{array}{l}\text { I and II } \\
\text { III* } \\
\text { and V† } \\
\text { Illegitimate }\end{array}$ & $\begin{array}{l}\mathbf{0} \\
\mathbf{3} \\
\mathbf{0} \\
\mathbf{0}\end{array}$ & $\begin{array}{r}0 \\
0.5 \\
0 \\
0\end{array}$ & $\begin{array}{l}5 \\
3 \\
3 \\
1\end{array}$ & $\begin{array}{l}2.0 \\
0.5 \\
0.9 \\
0.7\end{array}$ & $\begin{array}{r}16 \\
25 \\
10 \\
3\end{array}$ & $\begin{array}{l}1.9 \\
1.2 \\
0.9 \\
0.6\end{array}$ & $\begin{array}{r}12 \\
18 \\
7 \\
0\end{array}$ & $\begin{array}{l}1.3 \\
0.8 \\
0.6 \\
0\end{array}$ & $\begin{array}{r}7 \\
11 \\
9 \\
0\end{array}$ & $\begin{array}{r}0.9 \\
0.5 \\
0.8 \\
0\end{array}$ & $\begin{array}{r}40 \\
60 \\
29 \\
4\end{array}$ & $\begin{array}{l}1 \cdot 4 \\
0 \cdot 8 \\
0 \cdot 8 \\
0 \cdot 3\end{array}$ \\
\hline Total & 3 & 0.2 & 12 & 0.9 & 54 & 1.2 & 37 & 0.7 & 27 & 0.6 & 133 & 0.9 \\
\hline
\end{tabular}

* Includes students and unknown.

$\dagger$ Includes armed forces.

- Per 10,000 live births.

TABLE X

DEATHS FROM NEOPLASMS: DISTRIBUTION OF SOCIAL CLASS ACCORDING TO SITE WITH NUMBER AND RATES PER 10,000 CHILDREN

\begin{tabular}{|c|c|c|c|c|c|c|c|c|c|c|}
\hline \multirow{2}{*}{ Social Class } & \multicolumn{2}{|c|}{ Kidney } & \multicolumn{2}{|c|}{$\begin{array}{c}\text { Central Nervous } \\
\text { System }\end{array}$} & \multicolumn{2}{|c|}{ Leukaemia } & \multicolumn{2}{|c|}{ Remainder } & \multicolumn{2}{|c|}{ Total } \\
\hline & No. & Rate & No. & Rate & No. & Rate & No. & Rate & No. & Rate \\
\hline $\begin{array}{l}\text { I and II } \\
\text { III* } \\
\text { IV and V† } \\
\text { Illegitimate }\end{array}$ & $\begin{array}{l}6 \\
\mathbf{7} \\
\mathbf{2} \\
\mathbf{0}\end{array}$ & $\begin{array}{r}0 \cdot 2 \\
0 \cdot 1 \\
0 \cdot 1 \\
0\end{array}$ & $\begin{array}{r}8 \\
15 \\
12 \\
2\end{array}$ & $\begin{array}{l}0 \cdot 3 \\
0 \cdot 2 \\
0 \cdot 3 \\
0 \cdot 1\end{array}$ & $\begin{array}{r}17 \\
20 \\
7 \\
0\end{array}$ & $\begin{array}{r}0.6 \\
0.3 \\
0.2 \\
0\end{array}$ & $\begin{array}{r}9 \\
18 \\
8 \\
2\end{array}$ & $\begin{array}{l}0 \cdot 3 \\
0 \cdot 2 \\
0 \cdot 2 \\
0 \cdot 1\end{array}$ & $\begin{array}{l}40 \\
60 \\
29 \\
4\end{array}$ & $\begin{array}{l}1 \cdot 4 \\
0.8 \\
0 \cdot 8 \\
0.3\end{array}$ \\
\hline Total & 15 & $0 \cdot 1$ & 37 & $0 \cdot 2$ & 44 & $0 \cdot 3$ & 37 & $0 \cdot 2$ & 133 & 0.9 \\
\hline
\end{tabular}

* Includes students and unknown.

$t$ Includes armed forces. 
childhood leukaemias in Northumberland and Durham, found a social class distribution which he describes as 'not grossly different from the regional distribution', although there was a preponderance of the children of miners and agricultural workers in the 6 years and over age group.

On the other hand, in the occupational mortality statistics of the General Register Office for adults over the age of 15 years, a higher rate has consistently been found for the upper social groups for all forms of cancer which tend to predominate in childhood, e.g., leukaemia. In the U.S.A., many surveys have shown a decreased incidence of leukaemia in the lower socio-economic groups and in negro children (Boggs, Wintrobe, and Cartwright, 1962; Browning and Gross, 1968).

\section{ReSPIRATORY DISEASES}

Age and Sex. There were 528 deaths from respiratory diseases, giving a death rate of 3.4 per 10,000 children. The children who died in the neonatal period were those who suffered from 'pneumonia of the newborn', but it is difficult to assess the incidence in the early neonatal period as 'prematurity' may include some cases. The highest mortality was in the post-neonatal period with $25 \cdot 2$ deaths per 10,000 children, and deaths from respiratory disease were rare over the age of 2 years. The sex ratio of 60 boys to 40 girls is the same as that found in the Newcastle survey (Gardner, 1968).

Month of the Year. Table XI shows the distribution of deaths according to the time of year. As expected, the deaths showed a higher incidence in the winter than in the summer. As found by Elderkin, Gardner, Turk, and White (1965), the rise started in late summer and early autumn, reaching its peak in the early winter, unlike the adult deaths which reached their peak in the first quarter of the year. In Glasgow, Grist, Ross, and Stott (1967) found a peak incidence of notifications of pneu- $\bar{N}$ monia and respiratory infection over the age of 157 years in the first quarter of the year and under the age of 5 in the last quarter. They suggested that $\frac{\bar{m}}{\bar{m}}$ influenza and respiratory syncytial virus were $\vec{\nabla}$ outstandingly important as causes of epidemic respiratory disease of pneumonic severity in adults $\$$ and young children respectively. This pattern is also $\vec{O}$ in accordance with that found by the Medical $\vec{P}$ Research Council Working Party on Acute Res- $\mathcal{O}^{-}$ piratory Virus Infections (1965).

Place of Residence and Death. The place of residence of the children under 5 years showed the $\omega$ same distribution as that of all deaths, i.e., the rate $\vec{\omega}$ was higher in the inner than the outer boroughs, but $\sigma$ among older children respiratory deaths were more 9 frequent in the outer boroughs (Table XII). The $\vec{T}$ place of death showed a marked difference from that of the deaths as a whole, $59 \%$ only occurred in hospital, $7 \%$ on the way to hospital, and the remainder, $34 \%$, elsewhere. Seventy-six per cent ha $\vec{\theta}$ a coroner's necropsy. This last figure probabe reflects the suddenness of the deaths even amours those who survived long enough to get to hospitat If these deaths are to be prevented it suggests that either much earlier diagnosis is needed (which seems unlikely) or that some method is required of providing immunity to children under 2 years of age.

Social Class. As in the Newcastle Survey (Gardner 1968) and the national study of Douglas

TABLE XI

DEATHS DUE TO RESPIRATORY DISEASE ACCORDING TO MONTH OF DEATH

\begin{tabular}{|c|c|c|c|c|c|c|c|c|c|c|c|c|c|}
\hline & Jan. & Feb. & Mar. & Apr. & May & Jun. & Jul. & Aug. & Sep. & Oct. & Nov. & Dec. & Total \\
\hline $\begin{array}{l}\text { No. } \\
\text { Per cent distribution in London children }\end{array}$ & $\begin{array}{l}70 \\
13\end{array}$ & $\begin{array}{l}63 \\
12\end{array}$ & $\begin{array}{l}58 \\
11\end{array}$ & $\begin{array}{r}39 \\
7\end{array}$ & $\begin{array}{r}22 \\
4\end{array}$ & 23 & 25 & $\begin{array}{r}33 \\
6\end{array}$ & $\begin{array}{r}30 \\
6\end{array}$ & $\begin{array}{r}36 \\
7\end{array}$ & $\begin{array}{l}52 \\
10\end{array}$ & $\begin{array}{l}77 \\
15\end{array}$ & $\begin{array}{l}528 \\
100\end{array}$ \\
\hline $\begin{array}{l}\text { Per cent distribution for deaths due to } \\
\text { respiratory disease, all ages }\end{array}$ & 14 & 16 & 13 & 9 & 6 & 5 & 5 & 5 & 5 & 6 & 8 & 9 & 100 \\
\hline
\end{tabular}

TABLE XII

DEATHS FROM RESPIRATORY DISEASE ACCORDING TO PLACE OF RESIDENCE

\begin{tabular}{|c|c|c|c|c|c|c|c|c|}
\hline & \multicolumn{2}{|c|}{ Under 1 year } & \multicolumn{2}{|c|}{$1-4$ years } & \multicolumn{2}{|c|}{$5-14$ years } & \multicolumn{2}{|c|}{ Total } \\
\hline & No. & Rate* & No. & Rate* & No. & Ratet & No. & Rate† \\
\hline $\begin{array}{l}\text { Inner boroughs } \\
\text { Outer boroughs }\end{array}$ & $\begin{array}{l}214 \\
214\end{array}$ & $\begin{array}{l}36 \cdot 1 \\
26 \cdot 2\end{array}$ & $\begin{array}{l}35 \\
41\end{array}$ & $\begin{array}{l}1.9 \\
1.5\end{array}$ & $\begin{array}{r}5 \\
19\end{array}$ & $\begin{array}{l}0 \cdot 1 \\
0 \cdot 3\end{array}$ & $\begin{array}{l}254 \\
274\end{array}$ & $\begin{array}{l}4 \cdot 3 \\
2 \cdot 8\end{array}$ \\
\hline Total & 428 & 30.4 & 76 & 1.6 & 24 & 0.3 & 528 & 3.4 \\
\hline
\end{tabular}

* Per 10,000 live births.

t Per 10,000 children in each age group. 
TABLE XIII

DEATHS FROM RESPIRATORY DISEASE PER 10,000 CHILDREN IN EACH AGE GROUP ACCORDING TO SOCIAL CLASS

\begin{tabular}{|c|c|c|c|c|c|c|c|c|c|c|c|c|}
\hline \multirow{2}{*}{ Social Class } & \multicolumn{2}{|c|}{ Neonatal } & \multicolumn{2}{|c|}{ Post-neonatal } & \multicolumn{2}{|c|}{$1-4$ years } & \multicolumn{2}{|c|}{ 5-9 years } & \multicolumn{2}{|c|}{ 10-14 years } & \multicolumn{2}{|c|}{ Total } \\
\hline & No. & Rate & No. & Rate & No. & Rate & No. & Rate & No. & Rate & No. & Rate \\
\hline $\begin{array}{l}\text { I and II } \\
\text { III* } \\
\text { IV and Vt } \\
\text { Illegitimate }\end{array}$ & $\begin{array}{r}7 \\
33 \\
19 \\
14\end{array}$ & $\begin{array}{l}2 \cdot 7 \\
5 \cdot 0 \\
5 \cdot 7 \\
9 \cdot 1\end{array}$ & $\begin{array}{r}49 \\
163 \\
103 \\
40\end{array}$ & $\begin{array}{l}18 \cdot 8 \\
24 \cdot 6 \\
30 \cdot 6 \\
26 \cdot 8\end{array}$ & $\begin{array}{r}12 \\
27 \\
31 \\
6\end{array}$ & $\begin{array}{l}1.4 \\
1.3 \\
2.8 \\
1.1\end{array}$ & $\begin{array}{l}3 \\
8 \\
4 \\
1\end{array}$ & $\begin{array}{l}0 \cdot 3 \\
0 \cdot 3 \\
0 \cdot 3 \\
0 \cdot 2\end{array}$ & $\begin{array}{l}0 \\
3 \\
4 \\
1\end{array}$ & $\begin{array}{l}0 \\
0 \cdot 1 \\
0 \cdot 4 \\
0 \cdot 4\end{array}$ & $\begin{array}{r}71 \\
234 \\
161 \\
62\end{array}$ & $\begin{array}{l}2 \cdot 5 \\
3 \cdot 2 \\
4 \cdot 3 \\
4 \cdot 2\end{array}$ \\
\hline Total & 73 & $5 \cdot 2$ & 355 & $25 \cdot 2$ & 76 & 1.6 & 16 & 0.3 & 8 & $0 \cdot 2$ & 528 & 3.4 \\
\hline
\end{tabular}

- Includes students and not known.

† Includes armed forces.

and Blomfield (1958), there was a higher death rate, nearly double, in the lower than in the upper social class groups, which was consistent among all age groups (see Table XIII).

Association with Other Causes. Of the 528 deaths from respiratory disease, 26 had a congenital abnormality mentioned on the certificate, and of the 632 deaths assigned to congenital abnormality, 56 had mention of respiratory infection.

Special Enquiry. As deaths from respiratory disease were considered to be of interest, extra information was obtained in three London boroughs. With the cooperation of the Medical Officers of Health of Haringey, Hounslow, and Westminster, the birth notifications, maternity hospital discharge notes, and the immunization, health visitors', child health and school health records, where available, were examined. For some cases extensive and full notes were available but unfortunately they were too few to allow a full analysis of all the deaths. Case notes from three hospitals in the area were also examined, but as a high proportion of the children died at home or very shortly after entering hospital, it was found that the information obtained did not warrant the extra work involved in following these enquiries further.

Of the 56 children in this special enquiry, two had respiratory causes of death only recorded on the certificate but were found to be handicapped children, one being a spastic quadriplegic and the other being mentally subnormal; seven other children had secondary causes of death registered as follows: neonatal hepatitis, 1; strangulated inguinal hernia (a cot death with acute tracheobronchitis), 1 ; cerebral palsy, 1 ; sickle cell anaemia, 1 ; reticulosis, 1 ; asthma, 1 ; and fibrocystic disease, 1 . The birth weight was found for 49 of the children; $9(18 \%)$ weighed less than $5 \frac{1}{2} \mathrm{lb}$. $(2.5 \mathrm{~kg}$.). Those who weighed less than $5 \mathrm{lb}$. $(2 \cdot 2 \mathrm{~kg}$.) at birth all died within seven months and the length of life of the remainder showed a completely random distribution.

Suffocation. There were 38 deaths assigned to suffocation (excluding asphyxia and atelectasis at birth). Sixteen of the children died from 'true' suffocation, i.e., accidents such as suffocation from plastic bags or inhalation of foreign bodies. Twelve children were said to have died from inhalation of vomit or gastric contents and 10 were called accidental mechanical suffocation. It is to these two categories that sudden unexplained deaths or 'cot deaths' are usually assigned. The inhalation of vomit is often in fact a terminal occurrence rather than a cause of death. The literature on these deaths is extensive and confusing. It has been reviewed by Valdes-Dapena (1967). Different criteria are used by different authors. There are many theories about causation but the deaths are often said to be due to a fulminating and overwhelming respiratory infection. It may be that in London the high proportion of post-mortem examinations in an urban area within easy access of hospitals results in more careful certification of deaths. Alternatively it may be that in London the diagnosis of respiratory disease is more acceptable in winter than in summer. Nevertheless the patterns that have emerged for deaths assigned to suffocation are different from those seen for respiratory deaths, and this suggests that the aetiology is not the same for the two groups. The age range was younger, none being over 1 year old. The oldest child who died from accidental mechanical suffocation was 4 months old. Of those who died from inhalation of vomit, nine were under 6 months, one was aged 6 months to a year and two were a year old. Unlike deaths due to respiratory disease, the social class pattern appeared to be similar to that of the country as a whole. Five were in social classes I and II, nine were in social class III, five were in social classes IV and V, and two were illegitimate.

Seven of the children died in hospital, six on the way to hospital, and nine elsewhere. The high 
proportion who died after admission to hospital is rather surprising.

Twice as many deaths occurred during the second and third quarters of the year as during the first and fourth, which is quite different from the deaths due to respiratory disease. On the other hand, the country as a whole does not show this seasonal pattern for sudden deaths (Registrar General's Statistical Review for 1966). The day of the week was also examined but no particular pattern emerged.

Traffic Accidents and Burns and Scalds. The two major causes of accidental death were traffic accidents and burns and scalds. Traffic accidents included all deaths on the road, whether the child was in a motor car, on a bicycle or knocked down in the street.

Age and Sex. Table VII shows the age distribution and rates for each age group. The mortality rates were highest in the 1-4 year olds for burns and scalds, a high proportion of which were due to oil heaters setting fire to the house. The proportion of boys was $72 \%$ for traffic accidents and $55 \%$ for burns and scalds.

Time of Year. There is a marked difference in the seasonal variation for the two causes. Table XIV shows that deaths due to burns and scalds practically disappeared during the summer months, whereas the highest number of deaths due to traffic deaths occurred in this period.

Social Class. Among deaths due to traffic accidents, social class appeared to have little influence, but there was an increasing risk of death from burns and scalds with declining social class, as shown in Table XV.

Place of Residence and Death. Rates of deaths due to traffic accidents were slightly higher in the outer London boroughs than in the inner boroughs, but the pattern was completely reversed for death due to burns and scalds (Table XVI). Seventy-three per cent of the deaths due to traffic accidents occurred in hospital, $14 \%$ on the way to hospital, and the remainder elsewhere. On the other hand, the majority of deaths from burns and scalds
TABLE XV

DEATHS DUE TO ACCIDENTS SHOWING THE DISTRIBUTION ACCORDING TO SOCIAL CLASS, WITH RATES PER 10,000 IN EACH GROUP

\begin{tabular}{c|cc|cc}
\hline \multirow{2}{*}{ Social Class } & \multicolumn{2}{c|}{ Burns and Scalds } & \multicolumn{2}{c}{ Traffic Accidents } \\
\cline { 2 - 5 } & No. & Rate* & No. & Rate* \\
\hline I and II & 2 & 0.1 & 17 & 0.6 \\
III & 21 & 0.3 & 52 & 0.7 \\
IV and V & 22 & 0.6 & 25 & 0.7 \\
Illegitimate & 9 & 0.6 & 2 & 0.1 \\
\hline Total & 54 & 0.4 & 96 & 0.6
\end{tabular}

* Rate per 10,000 in each social class group.

TABLE XVI

DEATHS DUE TO ACCIDENTS SHOWING THE PLACE OF RESIDENCE AND RATE PER 10,000 CHILDREN UNDER IS

\begin{tabular}{l|cc|cc|cc}
\hline & \multicolumn{2}{|c|}{$\begin{array}{c}\text { Inner } \\
\text { Boroughs }\end{array}$} & \multicolumn{2}{c|}{$\begin{array}{c}\text { Outer } \\
\text { Boroughs }\end{array}$} & \multicolumn{2}{|c}{ Total } \\
\cline { 2 - 5 } \cline { 5 - 6 } & No. & Rate* & No. & Rate* & No. & Rate* \\
\hline Traffic accidents & 32 & 0.5 & 64 & 0.7 & 96 & 0.6 \\
Burns and scalds & 37 & 0.6 & 17 & 0.2 & 54 & 0.4 \\
\hline
\end{tabular}

* Rate per 10,000 children under 15 years of age.

occurred before the children got to hospital. Fortyfour per cent died in hospital, $25 \%$ on the way to hospital, and $31 \%$ elsewhere. All the deaths were certified by the coroner. One would expect a high proportion of accidental deaths to take place outside hospital. Many of the children who died elsewhere from burns and scalds died in house fires, asphyxia or carbon monoxide poisoning being the immediate cause of death. Some children died immediately in the traffic accident, others may have been moribund when taken to hospital, which underlines the importance of making effective treatment available quickly at the site of the accident, especially as traffic accidents are a major cause of death in children.

\section{SUMMARY}

The death registrations were examined of 3,222 children under 15 years of age who died in 1966 from a population of 1,542,280 resident in Greater London; 1,273 died from causes associated with some abnormality of pregnancy or birth, 632 from congenital abnormalities, 528 from respiratory diseases, and 133 from neoplasms. Ninety-five per

TABLE XIV

DEATHS DUE TO ACCIDENTS SHOWING THE SEASONAL VARIATION

\begin{tabular}{l|ccccccccccc|c|c|}
\hline & Jan. & Feb. & Mar. & Apr. & May & Jun. & Jul. & Aug. & Sep. & Oct. & Nov. & Dec. & Total \\
\hline $\begin{array}{l}\text { Traffic accidents } \\
\text { Burns and scalds }\end{array}$ & $\mathbf{2}$ & 4 & 10 & 9 & 10 & 9 & 8 & 15 & 7 & 12 & 6 & 4 & 96 \\
\hline
\end{tabular}


cent of deaths of infants under 1 month occurred in hospital; of the older children one-quarter died elsewhere, the highest proportion being among those who died from accidents and respiratory causes. Among the babies, the lower social class groups had the highest death rates but this effect declined so that for the 10-14 year old group the highest rates were found among social classes I and II. This was due to a significantly greater incidence of deaths from neoplasms among the higher social groups.

We should like to acknowledge the help we have received from Dr. J. L. Patton, Medical Officer of Health, London Borough of Haringey, Dr. R. L. Lindon, Medical Officer of Health, London Borough of Hounslow, Dr. J. H. Briscoe Smith, Medical Officer of Health, London Borough of Westminster, Professor T. E. Oppe and the staff of St. Mary's Hospital Medical School, and Dr. A. M. Adelstein and the staff of the General Register Office. We should particularly like to thank Miss Gillian Burgess, medical student at St. Mary's Hospital Medical School, and Mr. Stanley von Hofe, medical student at Vanderbilt University, Nashville, Tenessee, U.S.A. for their help in collecting and coding the data.

\section{REFERENCES}

Boggs, D. R., Wintrobe, M. M., and Cartwright, G. E. (1962). The acute leukaemias. Analysis of 322 cases and review of the literature. Medicine (Baltimore), 41, 163.

BrownING, D., and Gross, S. (1968). Epidemiological studies of acute childhood leukaemia. Amer. J. Dis. Child., 116, 576.

Butler, N. R., and Bonham, D. G. (1963). Perinatal Mortality, 1st report. Livingstone, London.
Campbell, A. C. P., Gaisford, W., Paterson, E., and STEWARD, J. K. (1961). Tumours in children. A survey carried out in the Manchester Region. Brit. med. J., $1,448$.

Douglas, J. W. B., and Blomfield, J. M. (1958). Children Under Five. Allen and Unwin, London.

Elderkin, F. M., Gardner, P. S., TurK, D. C., and WHITE, A. C. (1965). Aetiology and management of bronchiolitis and pneumonia in childhood. Brit. med. J., 2, 722.

GARDNER, P. S. (1968). Virus infections and respiratory disease of childhood. Arch. Dis. Childh., 43, 629.

Grist, N. R., Ross, C. A. C., and Stott, E. J. (1967). Influenza, respiratory syncytial virus and pneumonia in Glasgow, 1962-65. Brit. med. J., 1, 456.

Grundy, F., and LeWIs-FaniNG, E. (1957). Morbidity and Mortality in the First Year of Life-A Field Enquiry in 15 Areas of England \& Wales. Eugenics Society, London.

KNOX, G. (1964). Epidemiology of childhood leukaemia in Northumberland and Durham. Brit. J. prev. soc. Med., 18, 17.

Registrar General (1970). Statistical Review of England and Wales for 1966. Part III. Commentary. H.M.S.O., London.

Registrar General's Decennial Supplement (1957). H.M.S.O., London.

REPORT OF THE M.R.C. WORKING PARTY ON ACUTE RESPIRATORY VIRUS INFECTIONS (1965). A collaborative study of the aetiology of acute respiratory infections in Britain, 1961-4. Brit. med. J., 2, 319.

Stewart, A., WebB, J., and HewItT, D. (1958). A survey of childhood malignancies. Brit. med. J., 1, 1495.

Valdes-Dapena, M. A. (1967). Sudden and unexpected death in infancy. A review of the world literature, 1954-1966. Pediatrics, 39, 123. 